UDK 821.162.3-6 Janáček:Beran

Jernej Weiss

Filozofska fakulteta Univerze v Ljubljani

Philosophical Faculty, University of Ljubljana

\title{
The forgotten correspondence between two friends: Leoš Janáček (1854-1928) and Emerik Beran (1868-1940)
}

\section{Pozabljena korespondenca med prijateljema: Leoš Janáček (1854-1928) in Emerik Beran (1868-1940)}

Ključne besede: korespondenca, Leoš Janáček, Emerik Beran, Brno, Maribor

POVZETEK

Češka in Moravska sta skoraj tri stoletja pošiljali svoje glasbeno nadarjene sinove po svetu ter si $s$ tem prislužili vzdevek konservatorij Evrope. Val čeških glasbenikov je $v$ drugi polovici 19. stoletja segel tudi na Slovensko, kjer so kot glasbeni ustvarjalci, poustvarjalci in pedagogi odločilno prispevali $\mathrm{k}$ rasti mlade slovenske glasbene kulture in tako na prehod iz glasbeno-navdahnjenega diletantizma $v$ postopen kvalitativen in kvantitativen dvig glasbenega dela na Slovenskem. Med slednje prav gotovo sodi Emerik Beran, ki je tudi po selitvi iz rojstnega Brna na Moravskem v Maribor na Slovenskem leta 1898 , prek pisemske korespondence privatnega značaja ohranil tesne prijateljske vezi s svojim nekdanjim profesorjem na Orglarski šoli v Brnu Leošom Janáčkom.

Korespodenca med Janáčkom in Beranom ponuja dragocen vpogled $v$ njune glasbene ambicije, odnose do drugih kolegov, delovanje tamkajšnjih glashenih institucij ter kulturno in politično vadušje časa v katerem sta delovala. Janáček in Beran sta
Keywords: Correspondence, Leoš Janáček, Emerik Beran, Brno, Maribor

\section{SUMMARY}

Bohemia and Moravia were sending their musically talented sons into the world for nearly three hundred years thereby earning the title of Europe's conservatorium. A wave of Czech musicians also reached Slovenia in the second half of the $19^{\text {th }}$ century, where they decisively contributed to the growth of the young Slovene musical culture as composers, music performers and music pedagogues and thereby, to the passage from the musically-inspired dilettantism into a gradual high quality and quantity increase in the musical work in Slovenia. One of the latter is certainly Emerik Beran, who maintained close and friendly contacts with his former professor at the Brno Organ School, Leoš Janáček, through letters of correspondence of a private nature, even after moving from his birth town Brno in Moravia to Maribor in Slovenia in 1898.

The correspondence between Janáček and Beran gives us valuable insight into their musical ambitions, relations to other colleagues, the 
ves čas dopisovanja (od 1890 do 1928) ohranila zelo dober odnos, njuna korespondenca pa navaja več primerov njune medsebojne pomoči pri poklicnih zadevah. functioning of musical institutions and the cultural and political climate of those times. Janáček and Beran maintained very good relations throughout their letter-exchange period (from 1890 to 1928) and their correspondence provides evidence of several instances of mutual generosity as they helped each other in their careers.

Not only in Slovenia but also elsewhere in Europe, works on music history seem to be, as a tradition, strongly influenced by national criteria. Thus, music is too often merely observed within a defined national framework. On the contrary, a characteristic feature of the period cluring the transition to the $20^{\text {th }}$ century is the numerous pieces of correspondence, showing the high intensity and closeness of the composers', music performers' and music pedagogues' international dialogue. The topics of these pieces of correspondence are discussed again and again, but only rarely systematically researched.

Bohemia and Moravia were sending their musically talented sons into the world for nearly three hundred years thereby earning the title of Europe's conservatorium. A wave of Czech musicians also reached Slovenia in the second half of the $19^{\text {th }}$ century, where they decisively contributed to the growth of the young Slovene musical culture as composers, music performers and music pedagogues. One of the latter is certainly Emerik Beran, who maintained close and friendly contacts with his former professor at the Brno Organ School, Leoš Janáček, through letters of correspondence of a private nature, even after moving from his birth town Brno in Moravia to Maribor in Slovenia in 1898.

Among the twenty-one preserved letters from Janáček to Beran, written during 1890 and 1928, eight of Janáček's letters and eight of Janáček's postcards have been preserved, in addition to five official letters written during Beran's pedagogical work at the Organ School in Brno. Among twenty-one of Beran's letters to Janáček, written during 1911 and 1928, we can find eight of Beran's letters and thirteen of Beran's postcards, where in five of them, the place and time are not exactly given. ${ }^{1}$

Janáček corresponded with Beran mostly from Brno, and only rarely wrote to him from other places. On the other hand, Beran wrote most of his letters in Maribor where he worked until 1928. The only exceptions are later letters to Janáček's spouse, which were sent from Ljubljana.

I In spite of this, we can more or less precisely determine with regard to the content when each letter wats written. 
Beran was ever thankful to Janáček for his tutorship at the Brno Organ School, and therefore, several times emphasising in his letters, that it was "Janáček who had given the most to the school's students. " ${ }^{2}$ His opinion was that the Organ School set stricter criteria for promotion to a higher grade under his tutorship and was more "modern* than "the traditional" Prague Conservatorium. ${ }^{3}$ The study programme at that time "only" had three grades; however, the requirements were so extensive that students rarely managed to complete their studies in three years. ${ }^{4}$ Janáček undoubtedly saw a capable musician in Beran, excelling in "rich musical knowledge and with exceptional musical talent.." As the Organ School's Headmaster, he entrusted several pedagogical obligations at the only higher education institute in Moravia at that time (the Brno Organ School) to Beran after he had completed his musical studies at the age of 22. Janáček's official letters, sent to Beran during 1890 and 1896, show that Janáček had even consulted Beran in preparing programmes for the Organ School's production. The trust won by Beran with Janáček through his conscientious performance of pedagogical obligations and his "exemplary behaviour within the school soon grew into a close friendship. ${ }^{6}$ Thus Janáček had already begun addressing Beran with "Dear frienck while they were colleagues at the Brno Organ School. ${ }^{7}$

After Beran had left for Maribor in autumn 1898 , the correspondence between Janáček and Beran was interrupted for more than a clecale. It seems reasonable to find the reason why the musicians did not write to each other during that period in Beran's breaking off of any contacts with his mother country after his arrival to Slovenia. The disappointment because he could not get a permanent job in Moravia, ${ }^{8}$ and the disappointment after the love of his life (Roza Stvrtniček $)^{\%}$ had refused him was probably so painful for Beran that he even ceased his contact with Leoš Janáček. Although a more personal note between the correspondents in Janáček's official letters to Beran during 1890 and 1896 can be traced, it only appears openly in Janáček's congratulation to Beran upon his wedding with Marija Podolonik dated $1908 .^{10}$ Christmas and New Year greetings then preserve the continuity in their letter contacts until the beginning of World War I. However, their correspondence is not only marked with Christmas and New Year

2 The merits for the high professional level of the Organ School were mostly due to its pedagogic head and first headmatster, Leoš fanacek, who was always endeavouring to introduce new didactic and educational methods, thus gradually increasing the teaching level of the Organ School. Janácek as a capable organizer managed to put together an enviable teachers' assembly through the Institure's Supervisory Board, which consisted of the highest representatives of the worldly and church authorities in Brno of that time.

1 Beran wrote several times in his letters to janaćek that at the time of his studies, the Organ School's graduates had exceeded the Prague Conservitorium's graduates in their knowledge. See Beran's correspondence with Janíček located in Oddělení dějin luudby of Moravské zemské muzeum in Brno.

Thus only Emerik Beran and Cyril Metodèj Hrazdira successfully passed all examinations and completed their studies with a public diploma examination in the $1887 / 88$ Academic Year from among sixteen students of the last grade. See Beran's legacy in the Maribor University Library.

JANÁĆEK, LEOS, Brno, $30^{\text {th }}$ March 1893.

Ibidem.

JANÁČEK, LEOS, Brno, $20^{\text {th }}$ January 1896

Wishing to improve his financial situation, he applied to advertised posts in Bohemia, Moravia and Silesia, which is revealed from his great number of applications for the full-time post of a music teacher between 1890 and 1898 . As many as thirteen applications from this period were unsuccessful - six for posts at Czech and seven at German teacher training colleges. There were too many candidates for fulltime employment, but it was also partly due to banguage and nationality fights in Czech countries, in which relations were extremely strained. As Beran was employed at a Czech teacher training college, teaching there in the Czech language, his applications for German kacher training colleges were already doomed to failure in advance. On the other hand, the Caech institutes held a gructge against Beran because he hacl passed the statc professional examination in Vienna and not in Prague. In such a fighting atmosphere, saturated with mutual clislodgring, hoth sides used unprofessional criteria in occupying vacint posts. During the decade until 1898 , Beran's professional fate was thus, several times, left in the hands of the intolerant policy of national divisions. See Beran's legacy in the Maribor University Library.

"In numerous short love letters written from 1891 and 1898 , Beran showed his wish to get married to the love of his life, Roza Stvrtnixek, who, however, was not intended for him. He declicated numerous musical works to her: on $14^{\text {th }}$ July 1892 , Tuo love songs for the piano, on $26^{\text {th }}$ August 1892, the piano extract of the cantata Rama, on $25^{\text {th }}$ May 1893 , the solo Lotos blossom, and on $26^{\text {th }}$ August 1893 , on her $17^{\text {th }}$ birthday, Six saloon works for the piano. Beran's w13rno muse*, Rozal Sivrtnicek, was eight years younger than Emerik. After she had left for Maribor, Beran was grieved that he had lost his love in Brno and never saw her again as she had married another man. She was said to have remembered the young Beran, who used to be her teacher in Brno, several times. See Beran's legacy in the Maribor University Library.

10 JANẢCEK, LEOŠ, Bmo, $19^{\prime \prime \prime}$ May 1908. This was the first Janjéck's letter to Beran in the $20^{\prime \prime \prime}$ century. 
greetings. Thus Janáček expressed his condolences to Beran over the death of his father, Vincenc Beran, in his telegram dated 1914. ${ }^{11}$

Beran tried to mediate with Janáček in the same year for the premiere staging of the operetta Princesa Vrtoglavka (The Dizzy Princess) by the Slovene composer Josip Ipavec (18731921), whose Viennese tutor during 1904 and 1905 was Alexander Zemlinsky. Probably it was just the closing of the Ljubljana Opera House in 1913 that encouraged Ipavec to intensively search for contacts with other opera theatres, after there was no possibility of performing his operetta in Ljubljana. ${ }^{22}$ The surname of Ipavec was certainly not unknown in the Moravian capital since the opera Teharski plemiči (The Teharje Noblemen) of Josip's uncle Benjamin had been performed there in 1895 . Beran was immediately willing to help Ipavec and also wrote to Janáček in this sense. ${ }^{13}$ The latter was an undisputable authority in the Brno musical circles in the opera field at that time and could have influenced the theatre administration with his reputation so that they would include Ipavec's operetta in their programme. ${ }^{1.4}$ In his answer to his former student, Janáček assessed Ipavec's work well and asked Beran to also send him his own opera Melusina so that he would also try to mediate for its premiere staging in the Brno theatre. ${ }^{15}$ Beran informed Ipavec of the favourable outcome of his intervention without delay, and at the same time also reported to him about the situation in the opera orchestra in Brno as Janáček had described it in his letter to him: "The group is sufficiently large and sufficiently capable of co-operating in opera performances such as Fidelio, Dalibor or Carmen." ${ }^{16}$ He also informed Ipavec that a successful premiere in the Moravian capital would probably also ensure his operetta a performance in Prague, from where Princesa Vrtoglavka could continue its victorious march through the world musical stages. At last, Beran asked Ipavec to write to Janáček himself: "You can also write in Slovene since the Master is a keen Slav." ${ }^{17}$ However, only a few days after that, fatal shots resounded in Sarajevo and the world was plummeted into the catastrophe of World War I.

In spite of the war, the correspondence between Janáček and Beran remained uninterrupted. It even seems that the hope for the times which would be more in favour of the Slav idea connected them even more closely and thus strengthened their correspondence during the War. Their main bond seems to be Beran's dissatisfaction, which is most probably due to ever stronger German ideological pressures with regard to "everything of Slav character" and Beran's concerns due to the (non)staging of Melusina.

Beran thus asked Janáček in his letters from that period several times whether a premiere of his opera could be staged in Plzen̆, where he had achieved great success as a composer during his work in Brno. ${ }^{18}$ From the creation of Melusina in 1896, Beran had consistently endeavoured to have it staged and had sent the opera to various addresses, but was refused

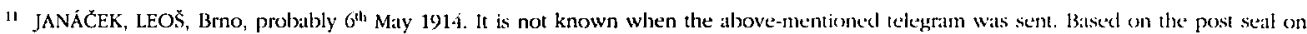
the telegram, we can assume that Janacek sent it to Beran on $6^{\text {th }}$ May 1914.

12 GRDINA, IGOR, Ipalci: zgudovina slovenske meščanske dinastije, ZRC SAZI), Ijulbljana 2001, 437-438.

13 BERAN, ENERIK, Maribor, $24^{1 / 1}$ May 1914.

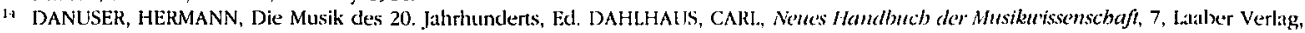
Laber 1984, 49.

15 JANÁČEK, LEOṠ, 16 June 1914

16 Ilsidem.

17 BERAN, EMERIK, Maribor, 17' June 1914. Both the Czech and Slovene languages are descended from Proto-Slavic, a Western offshoot of the Eastern Indo-European ('saten') group of languages. It took approximately three millennia for the Proto-Slavic language to evolve. Even towards the end of the first millennium AD, the Slavic language was still essentially uniform in its grammar and phonology. WINGFIEL.D, PAUL, Janăčck: Glagolitic Mass, Cambridge University Press, Cambridge 1992, 27.

is On $21^{\text {s }}$ November 1897 , Beran's Legenda I (Legend 1) for orchestra (marked Ossian-) achieved a splendid success with the pulblic. Mortuske Listy. No. 12, $24^{\text {th }}$ November 1897 . 
each time. ${ }^{19}$ At last, he offered it to the theatre in Zagreb just prior to the beginning of World War I, but the opera was not included in the theatre programme. After his last unsuccessful attempt, he abandoned all efforts for its staging for more than a decade.

Beran as a decided Panslavist and Russophile was, in principle, against everything Austrian. In his interest for the Russian world, he followed Janáček's direction to the Slavonic East. ${ }^{20}$ In spite of German pressures, he confessed his Czech origin and that his ideas had always belonged to the Czech nation. Janáček was pleased with Beran's national pride and wrote: "I can feel from your letter that you have not lost your Czech soul abroad.."11 Janáček felt Beran's distress, which was a consequence of stronger and stronger pro-German pressures and also of Beran's long-term pedagogical work. In his letter from this period, Janáček wrote: "It is easy for me to believe that you have enough of teaching at the Teacher Training School. I myself cried with pleasure when I had escaped from this torture chamber! You are young and you still have the time for composing."22 Janáček retired in 1904, when he was only 50, and afterwards, in the pedagogical field, dedicated himself solely to teaching at higher schools. Beran was 60 when he returned to the Higher Musical School once more. He had worked in schools practically all his life. It seems that Beran chronically lacked time to compose just due to his too extensive pedagogical obligations.

Beran somehow idealistically hoped that after the end of the war, a number of things would change for the better in Slovenia. ${ }^{23}$ He and Janaček believed in the final solution of the national question - the nations living in the former Austro-Hungarian Monarchy. ${ }^{24}$ Because of his clissatisfaction with the situation in Slovenia, Beran started to seriously think about applying for a job at the Brno Conservatorium after the establishment of the first Czech-Slovak Republic in 1918 when he was 50. It was especially Janáček, who persistently encouraged him to apply from the very beginning, since especially after the end of the war, he continually complained about the level of the pedagogical work at the Brno Conservatorium. ${ }^{25}$ Janáček was so dissatisfied with the poor pedagogical situation at the Conservatorium that he even wrote in his

19 After the first performance of Jenufa, Janaces also faced a similar fate while allewlyting for over a decade in vain to have the opera staged with the Director of the Operal of the Prague National Theatre, Karl Kowarovic. The latter continually expresseci the technical shortcomings of the score only allowing the premiere after he himself had revised the score. He thus conducted the premiere performance of the opera in Prague on 26 May 1916. The Prague staging widely opened the cloor of the European opera stages for Jenufa. It is interesting that among the first performances of the opera albroad, we can also find the premiere staging of Jenufa on the stage of the Ljubljana Opera housc on $28^{\mathrm{th}}$ October 1922. ŠTĔDROŇ, BOHUMír, Leašjanciček: Vzpominky, dokumenty, korespondence a sindie, Editio Supraplon, Prah:

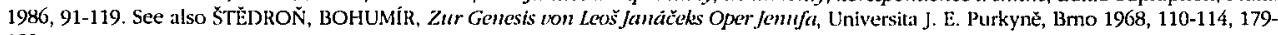
183.

20. In 1883, even a disciplinary procedure was initiated against Janictek at the German teacher training college in Brno as his national fanaticism bordered on insanity: Janacek worked at the alove-mentioned teacher training college as an auxiliary music teacher from 1872 , and from 1880 onwards as its main music teacluer. Therefore, it is not surprising that he deeply influenced the young Beran with his example during cleven years. Beran worked al bolh schools in Brno where also Janácét taught (in addition to the above-mentioned teicher

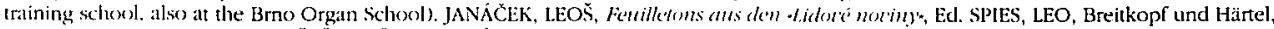

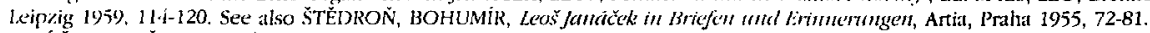

$\therefore$ JANÁĆEK, L.EOS , Bmo, $21^{\text {th }}$ May 1915.

22 Ibidem.

2.5 After it seemed that nothing worse could happen to the Slovenes than the past -horror years-, a new national disaster arose and with it, a new test of emancipation for the Slovene nation. In the first years after the war, the Slovenes lost the Primorje region through the Rapallo Treaty (12 $2^{\text {th }}$ November 1920$)$ and with the Carinthian plebiscite $\left(10^{\text {li }}\right.$ October 1920$)$, the country of their historical beginnings - Carinthia. The price the slovenes had to pay for having decided for Yugoslavia in the years after World War I was thus far from low, as more than One quanter of the Skovenc population and territories had been cut off from their homeland. PEROVŠEK, JURIJ, Iz. Avstrije $v$ Jugoslavijo, Ed. MARJAN DRNOVŠEK, DRAGO BAJT, Slotxenska knomika XX, sloletja, Nova revija, Ljubljana 1995, 203.

2t The Austrian German bourgeosisie and conservative aristocratic elites which were prepared to make a compromise with Hungary, the ftalian provinces and the Polish Galicia refused any Czech or Slovene attonomy until the disintegration of the Austrian-Hungarian monarchy. The Slovene national-political prospects strongly deteriorated in spring 1916, when German political parties in Austria demanded an immediate constitutional act in their political programme whereby one half of the entire Austrian state would be transformed into a German national state. Therelby the Czech and the Slovene nations would be doomed to national death. The latter hoped, after the end of World War 1 in Novenber 1918, to get more autonomy in the newly founded -Slavic-countries (the first Caech-Slovak Republic and the Kingdon of Serls, Croats and Slovenes). PRUNK, JANKO, Kratka zgodor'ina S/ourenije, Založlba Grad, Ljubljana 2002, 85-86.

i5 In his letter to Karl Koviliovic dated $30^{\text {th }}$ Septemler 1918, he writes: Among my collealgues at the Bmo Organ Sclool, I feel as a bumblebee catught belind a window pane who doesn't know how to get back out to freedom.. VOGEL. JAROSLAV, Leos.janácek: žitot a dilo, Státni hudeloni vydavatelstvi, Prahal $1963,153$. 
letter to Beran that there was nothing for him to do there: "Here, practically all jobs are occupied although not always with the best capacities. Especially not at this Conservatorium! I assume that you will soon retire? Will you come back then?" ${ }^{26}$ Janáček's open judgement of some professors of the Brno Conservatorium is interesting. It is obvious that Janácek assessed Beran as more suitable for the pedagogical work there. Thus he wrote in his letter to Beran: "I think that through your origin you belong to us. Apply, but soon! Send your application form directly to the Institute's Headmaster's Office. ${ }^{27}$ Beran did not respond to Janáček's invitation to return to his former post in Brno. He still had to work six years until his retirement and he was already quite of age. He became a citizen of the Kingdom of Serbs, Croats and Slovenes and continued his employment without any interruption at the State Men's Teacher Training School in Maribor. Practical reasons thus had priority over the mother country's call. That the second option must have been quite strong and that the circumstances there were more attractive for Beran than at any time before can probably be assumed clue to the ideological change which happened after the end of World War I in Brno which remained pro-German nearly until that time. ${ }^{28}$ Janáček in his letter to Beran reported that many new things were happening in Brno. He wrote that both the Municipal Theatre and the town itself were in their hands from that time on. ${ }^{29}$

Beran's last working years in Maribor were not simple for him as he was afflicted with several quite serious illnesses. ${ }^{30}$ Perhaps it was due to the abundance of free time during his sick leave during 1924 and 1925 that his correspondence with Janáček became the most intensive ever, since more than one half of them were written at that time. Upon the awarding of an honour's cloctorate to Janáček, awarded to him on $28^{\text {th }}$ January 1925 by the Masaryk University in Brno, Beran visited Brno on Janáček's invitation for the last time. In his letters from that time, Beran again mentioned Melusina, which he wanted to send to Janáček. It seems that attempts to stage the opera abroad were once again made in this time. However, it is not clear from the correspondence whether Beran indeed sent Melusina to Janáček. Undoubtedly, he had lost confidence in the theatre administration there.

Both Beran and Janáček were aware of their different esthetical views and directions as composers. Therefore, they only rarely discussed issues of aesthetics and composition in their correspondence. Beran adhered to the traditional musical sentence all his life. ${ }^{31}$ They preferred discussions on topical questions of an organisational nature. Thus after his departure to the Ljubljana Conservatorium in 1928, Beran searched with Janáček through the final grade of students at the Conservatorium in Brno for those who would be prepared to teach at the Conservatorium in Ljubljana several times. Yet, Beran's calls to Janáček, except for some exceptions, did not

26 JANÁČEK, LEOŠ, Brno, $9^{\text {1l }}$ January 1919.

27 JANÁCEK, LEOŚ, Luhačovice, $25^{\text {th }}$ July 1919.

24 In Moravian towns, the fights between the German majority and the Czech minority were the worst in the towns in Moravia in the nineties of the $19^{13}$ century. The conflicts were especially grave in Brno where the Germans maintained the strongest influence wirh a convincing majority. In the provincial assembly, it was only in 1905 that the two nations decided on negotiations, which led to a partial settement (•Ausgleich-) by changing the electoral order and a compromised arrangement on some other disputed issues. LÉBL, Vl.ADIMíR. Hudl’a at společnost, Ed. Ústav hudebni vědy Československé akademic věd, Déjiny české hudebmi kultuṛ' 1890/1945, 1, Açademia l’raha, P’raha 1972, 253-260.

29) JANÁČ́EK, LEOŠ, Luhačovice, $25^{\text {hn }}$ July 1919.

30) Beran had alleady asked to be retired because of his chronically repeated health problems on $31^{\mathrm{N}}$ july 1923 . His work-pedagogical path runs without any interruption from his first employment on $16^{\text {1h }}$ April 1890 to his retirement on $25^{\text {th }}$ July 1926 . On $18^{\text {th }}$ Octolecr 1912 he went on sick-leave in the winter semester, which he extended until the 1912/13 Academic Year. From $17^{\text {th }}$ November 1921 to $17^{\text {th }}$ Feluruary 1922. Beran wis again given a three-month sick-leave. The reason for Beran's illness problems is not known. See Beran's legacy in the Maribor University Library.

3 Contrary to this, we can trace the composer's explicit aesthetic direction to new music in Janicek's musical poetics, especially during the last decade of his creating, in spite of the seemingly traditional conceptual starting points. EWANS, MiCHAEL, Janazek 's Tagic Operas, Indiana University Press, Bloomington and London 1977, 13-33. See also STRÖBEL, DIETMAR, Moliv und Figur in den Kompositionen der Jenufa - Werkgruppe Leoš janíčks, Ed. EGGEBRECHT, HANS HEINRICH, Freibunger Scbriften zur Musikwissenscbaft, 6, Musikverlag Emil Katzbichler, München and Salzburg 1975, 14-18. 
bear the desired fruits. ${ }^{32}$ Most probably he was also searching among them for his successor who could replace him after his retirement at the Ljubljana Conservatorium. Beran's pedagogical load at the Conservatorium in Ljubljana was even higher than that at the Organ School in Brno. ${ }^{33}$

Beran saw Janáček for the last time at the Maribor railway station in autumn 1925. Janáček and his wife Zdenka had travelled by train to attend the Musical Festival in Venice. ${ }^{3 \cdot 1}$ They travelled through Maribor, where Beran was waiting for them with his family. A year later, Beran, who had obviously attended this Musical Festival, sent his best regards to Janáček from there. In spite of the fact that Beran called festival novelties "exaggerations" in his letter, they were nevertheless interesting for him. ${ }^{35}$ Beran could not follow them as far as the composition was concerned, but did not refuse them as an idea.

The last preserved pieces of their correspondence are from 1928. Beran, together with his wife Marija, traditionally sent Janáček a Christmas and New Year greeting card. Janáček in his reply to Beran, precisely seven months prior to his death, wrote that he would be extremely pleased if he could see him again.

The close friendship between Beran and Janáček is also revealed by the continued correspondence with Janáček's wife in the thirties. Beran did not only report on family and professional matters but also asked Janáček's wife to mediate in the staging of his opera. ${ }^{36}$ In his letter, he wrote that he would be extremely happy if his Melusina was finally staged. It is supposed that he even discussed the staging with the Brno Opera's Headmaster at that time. However, the latter was supposedly rather reserved to stage it in their theatre. Beran also wrote that he was still hoping for better times for his opera. In his last letter to Janáček's wife, he also mentioned that Melusina was still lying waiting in his drawer. ${ }^{37}$ In the same letter, he also wrote that he was losing hope that he would ever see its first performance.

In spite of many efforts to stage it, Beran never saw the first performance of his only opera. In fact, the opera has been waiting for more than a century after its creation in the musical archives of the Maribor University Library for its premiere staging. Although it seems that the step-motherly treatment of Jenufa and Melusina says a lot about the degree of importance Janáček and Beran faced in their musical cultural environments, the various demands of the environment in which they worked should be described in more detail in order to determine their roles more comprehensively. Great Czech composers such as Smetana, Dvorák and Janáček, among others, probably could not have done as much in Slovenia in the second half of the $19^{\text {th }}$ century and at the beginning of the $20^{\text {th }}$ century as did many "unknown" Czech musical immigrants, since the gap between their expectations and the environment's requirements would be probably too wide. Thus the sound craftsmanship of the numerous representatives of musical immigrants to Slovenia in the musical-productive, musicalreproductive and musical-pedagogical fields seems to be exactly what the Slovene musical culture needed in the early phase of its development.

32 The most interesting among them seems to be Beran's study colleague at the Brno Organ School, Cyril Metodĕj Hrazdira, who conducted at the first performance of Jenufa in the German Opera Theatre in Brno on $21^{\text {st }}$ January 1904 . Hrazdira succeeded Vaclav Talich as alue main conductor of the Slovene philharmonic society and of the Ljubljana Opera conductor in the 1912/13 season. CVETKO, DRAGOTIN, Slovenska glasba v europskem prostoni, Slovenska matica Ljubljana, Ljubljana 1991, 344-350.

3t In the first five years, his teaching obligations at the Brno Organ School were 22 to 26 hours weekly and later, 20 hours weekly. See Beran's legacy in the Maribor University Library.

14 Between $3^{\text {rel }}$ and $8^{\text {th }}$ October 1925, Janaceck attended the third festival -Internationalen Gesellschaft für zeitgenössische Musik- in Venice with his spouse. At the festival, Janiček's string quartet after The Kreutzer Sonata (1923) was also performed with great success. JANÁČEK, LEOŠ, Fenilletons ats den aLdovi noviny, Ed. SPIES, LEO, Breitkopt und Härtel, beipzig 1959, 137.

35 IBERAN, EMERIK, Venice, $20^{\text {th }}$ October 1926.

W. Further close connections between Beran anç Jałnacek's spouse Zdenka (born Schulz) are surprising as Janaicek's marriage was slowly losing its meaning during the last decade of his life due to Janácek's friendship with Kamilla Stössl. SUSSKIND, CHARLES, Jamiócek and Brod, Yale University Press, New lfaven and Lonckon 1985, 54-57.

BERAN, EMERIK, I.jubljiana, $22^{\text {nut }}$ December 1936. 


\section{Bibliography}

Emerik Beran's correspondence with Leoš Janáček (See Janáček's archive and Oddělení dějin hudby of Moravské zemské muzeum in Brno).

Leoš Janáček's correspondence with Emerik Beran (See Beran's legacy of the Maribor University Library).

BECKERMAN, MICHAEL, Janáček as Theorist, Pendragon Press, New York 1994.

BRABCOVÁ, JITKA, Zum Konzertleben in Brno um 1900 und Leoš Janáček, Ed. PEČMAN, RUDOLF, Collogutium Duorăak, Janăček and Their Time, 19, Mezinárodní hudební festival, Brno 1985, 81-86.

CVETKO, DRAGOTIN, Slovenska glasba v europskem prostoni, Slovenska matica, Ljubljana 1991.

DANUSER, HERMANN, Die Musik des 20. Jahrhunderts, Ed. DAHLHAUS, CARL, Neues Handbuch der Musikwissenschaft, 7, Laaber Verlag, Laaber 1984, 48-62.

EWANS, MICHAEL, Janáček's Tragic Operas, Indiana University Press, Bloomington and London 1977.

FUKAČ, JIŘÍ, Der Prozeß der Janáček-Rezeption und seine allgemeinen und spezifischen Züge, Ed. PEČMAN, RUDOLF, Colloquium Leoš Janáček ac tempora nostra, 13, Mezinárodní hudební festival, Brno 1983, 311-319.

GRDINA, IGOR, Ipavci: zgodovina slovenske meščanske dinastije, ZRC SAZU, Ljubljana 2001.

JANÁČEK, LEOŠ, Feuilletons aus den •Lidové noviny», Ed. SPIES, LEO, Breitkopf und Härtel, Leipzig 1959. KUNDERA, MILAN, Mưi Janãček, Atlantis, Brno 2004.

LÉBL, VLADIMÎR, Hudba a společnost, Ed. Ústav hudebni vědy Československé akademie věd, Dějiny české budebni kultury 1890/1945, 1, Academia Praha, Praha 1972, 253-260.

PEROVŠEK, JURIJ, Iz Avstrije v Jugoslavijo, Ed. MARJAN DRNOVŠEK, DRAGO BAJT, Slovenska kronika XX. stoletia, Nova revija, Ljubljana 1995, 203-206.

PRUNK, JANKO, Kralka zgodovina Slovenije, Založba Grad, Ljubljana 2002.

SCHNEBEL, DIETER, Das späte Neue, Ed. HEINZ-KLAUS METZGER, RAINER RIEHN, Musik-Konzepte: Leoš Janáčck, 7, Universal Edition, 75-90.

STRÖBEL, DIETMAR, Motiv und Figur in den Kompositionen der Jenufa - Werkgruppe Leoš Janáčeks, Ed. EGGEBRECHT, HANS HEINRICH, Freiburger Schriften zur Musikwissenschaft, 6, Musikverlag Emil Katzbichler, München and Salzburg 1975.

SUSSKIND, CHARLES, Janáček and Brod, Yale University Press, New Haven and London 1985.

ŠTĚDROŇ, BOHUMír, Leoš Janáček in Briefen und Erinnenungen, Artia, Praha 1955.

ŠTĚDROŇ, BOHUMÍR, Leoš Janáček: Vzpominky, dokumenty, korespondence a studie, Editio Supraphon, Praha 1986.

ŠTĚDROÑ, BOHUMír, Zu Janáčeks Oper Jenufa in den Jahren 1916-1918, Ed. PEČMAN, RUDOLF, Colloguium Leǒ̌ Janáček et Musica Europaea, 3, Mezinárodní hudební festival, Brno 1970, 145-152.

ŠTĚIDROÑ, BOHUMÍR, Zur Genesis von Leoš Janáčeks Oper Jenufa, Universita J. E. Purkyně, Brno 1968.

VYSLOUŽIL, JIŘí, Janáčeks versuch um die mährische Nationaloper, Ed. KURET, PRIMOŽ, „Opera socialni ali politični angažma?n, Festival Ljubljana, Ljubljana 1993, 158-163.

VOGEL, JAROSLAV, Leoš Janáček: żivot a dîlo, Státní hudební vyclavatelství, Praha 1963.

WINGFIELD, PAUL, Janáček: Glagolitic Mass, Cambridge University Press, Cambridge 1992. 